\title{
Economic Burden of Cardiovascular Diseases in the Russian Federation in 2016
}

\author{
Anna V. Kontsevaya, Oxana M. Drapkina, Yulia A. Balanova*, Asia E. Imaeva, \\ Evgenia I. Suvorova, Mihail B. Khudyakov \\ National Medical Research Center for Preventive Medicine \\ Petroverigsky per. 10, Moscow, 101990 Russia
}

\begin{abstract}
Aim. To evaluate the economic burden of cardiovascular diseases (CVD) in the Russian Federation (RF) in 2016, including the direct costs and the economic losses caused by reduced productivity.

Material and methods. Main data sources: data of the Federal state statistics service, data of state statistical reporting (forms №14, №141, №12 and №16-VN), and data of State Guarantee Program of Free Medical Care to the Citizens of the RF, statistical data of CVD, ischemic heart disease (IHD), myocardial infarction, cerebrovascular diseases, stroke. The direct medical costs were calculated based on the number of hospitalizations, including daycare center, emergency calls and outpatient visits due to CVD using the costs of the State Guarantee Program. The amount of disability benefits payments was calculated based on the number of disabled persons from each group and by the amount of the disability allowance. Indirect costs (economic losses) included a shortage of gross domestic product (GDP) due to premature mortality and disability in economically active age and loss of earnings due to temporary incapacity for work. The potential years of life lost (PYLL) were calculated using the number of life years not reached in economically active age due to premature death. Losses associated with premature mortality in the economically active age included unproduced GDP due to lost life years in the corresponding age group due to deaths from CVD, meaning the population' employment rate. Statistical analysis was performed by Microsoft Excel 10.0.

Results. PYLL due to premature death from CVD - 4.5 million years of potential life in economically active age, mostly men (3.3 million PYLL). Among almost $50 \%$ of men PYLL were due to ischemic heart disease. Economic burden because of CVD in 2016 in the RF reached 2.7 trillion 7 , which is equivalent of $3.2 \%$ of GDP for this year. In the structure of burden among all blood circulatory system diseases, IHD was in the first place (over 1 trillion $\mathrm{P}$ ). In the burden structure, direct costs were only $8.1 \%$, losses in the economics $-91.9 \%$ of the total burden. In the cumulative burden of CVD, IHD determined as $39.8 \%$ (over a trillion P), cerebrovascular diseases - fifth part (560 billion $¥$ ); strokes and heart attacks - 424 billion $\mathrm{P}$ and 213.1 billion $\mathrm{P}$, respectively.

Conclusion. The economic burden because of CVD in the RF in 2016 was 2.7 trillion $\$$ (3.2\% of GDP). Economic losses caused by premature mortality of people in economically active age prevailed in the structure of the burden (over $90 \%$ ). Such the significant economic burden is a weighty argument for increasing investments in the prevention and treatment of CVD.
\end{abstract}

Keywords: cardiovascular diseases, economic burden, risk factors, health care system expenses.

For citation: Kontsevaya A.V., Drapkina O.M., Balanova Y.A., Imaeva A.E., Suvorova E.I., Khudyakov M.B. Economic Burden of Cardiovascular Diseases in the Russian Federation in 2016. Rational Pharmacotherapy in Cardiology 2018;14(2):156-166. DOI: 10.20996/1819-6446-201814-2-156-166

\author{
Экономический ущерб от сердечно-сосудистых заболеваний в Российской Федерации в 2016 году \\ Анна Васильевна Концевая, Оксана Михайловна Драпкина, Юлия Андреевна Баланова*, Асия Эмверовна Имаева, \\ Евгения Игоревна Суворова, Михаил Борисович Худяков \\ Национальный медицинский исследовательский центр профилактической медицины \\ Россия, 101990, Москва, Петроверигский пер., 10
}

\begin{abstract}
Цель. Определить экономический ущерб от сердечно-сосудистых заболеваний (СС3) в России в 2016 г., включая прямые затраты системь здравоохранения и непрямые потери в экономике, обусловленные снижением производительности труда.

Материал и методы. Основные источники данных: данные Федеральной службы государственной статистики, данные годовых форм Федерального статистического наблюдения (ф.14, ф141, ф.12 и ф. 16-ВН), показатели Программы государственных гарантий бесплатного оказания гражданам медицинской помощи, статистические данные по ССЗ, ишемической болезни сердца (ИБС), инфаркту миокарда, цереброваскулярным заболеваниям (ЦВЗ), инсульту. Расчеты прямых медицинских затрат производились на основании количества госпитализаций, включая дневной стационар, вызовов скорой медицинской помощи (СМП) и амбулаторных посещений по поводу ССЗ с использованием стоимости по Программе государственных гарантий. Объем выплат пособий по инвалидности рассчитывали по количеству инвалидов каждой группы и по величине пособия по инвалидности. Непрямые затраты (экономические потери) включали недополучение валового внутреннего продукта (ВВП) вследствие преждевременной смертности и инвалидности в экономически активном возрасте и потери заработка из-за временной нетрудоспособности. Были рассчитаны «потерянные годы потенциальной жизни» (ПГПж) - число лет жизни, недожитых в экономически активном возрасте из-за преждевременной смерти. Потери, связанные с преждевременной смертностью в экономически активном возрасте, включали непроизведенный ВВП вследствие потерянных лет жизни в соответствующей возрастной группе по причине смерти от ССЗ с учетом коэффициента занятости населения.
\end{abstract}

Результаты. ПГПЖ из-за преждевременной смерти от ССЗ - 4,5 млн лет потенциальной жизни в экономически активном возрасте, преимущественно, за счет мужчин (3,3 млн ПГПЖ). Почти 50\% ПГПЖ мужчин обусловлены ИБС. Экономический ущерб от ССЗ в России в 2016 г. составил 2,7 трлн Р, что эквивалентно 3,2\% ВВП за этот год. В структуре ущерба среди всех болезней системы кровообращения ИБС удерживает первое место (свыше 1 трлн Р). В структуре ущерба прямые затраты составили всего лишь 8,1\%, потери в экономике - 91,9\% совокупного ущерба. В совокупном ущербе от ССЗ 39,9\% составляет ИБС (свыше 1 трлн Р), пятую часть - ЦВ3 (560 млрд Р), 424 млрд Р и 213,1 млрд Р - инсульты и инфаркты, соответственно.

Заключение. Экономический ущерб от ССЗ в России в 2016 г. составил 2,7 трлн ₹ (3,2\% ВВП). В структуре ущерба (свыше 90\%) преобладают потери в экономике, обусловленные преждевременной смертностью лиц экономически активного возраста. Столь значимый экономический ущерб - весомый аргумент в пользу увеличения инвестиций в профилактику и лечение ССЗ. 
Ключевые слова: сердечно-сосудистые заболевания, экономический ущерб, затраты системы здравоохранения.

Для цитирования: Концевая А.В., Драпкина О.М., Баланова Ю.А., Имаева А.Э., Суворова Е.И., Худяков М.Б. Экономический ущерб сердечно-сосудистых заболеваний в Российской Федерации в 2016 году. Рациональная Фармакотерапия в Кардиологии 2018;14(2): 156-166. DOI: 10.20996/1819-6446-2018-14-2-156-166

*Corresponding Author (Автор, ответственный за переписку): jbalanova@gnicpm.ru

Received / Поступила: 23.01.2018

Accepted / Принята в печать: 23.03.2018

Cardiovascular diseases (CVD) are characterized as a significant socioeconomic burden, both for the health care system and for the economy as a whole [1], and are regarded as a priority in the long-term socio-economic development of the Russian Federation (RF) [2]. CVD burden can be very significant, since it is not only the costs of treatment, but also the economic losses associated with disability, reduction in productivity and premature mortality $[3,4]$. For example, ischemic heart disease (IHD) is the leading cause of disability in Europe, accounting for $10 \%$ of all years living in a state of disability [5].

The analysis of the economic burden of the disease can be a tool for assessing the effectiveness of spending health care system resources and justifying investments in prevention and treatment to reduce the burden of disease primarily by reducing losses in the economy. For example, the economic burden of CVD in the USA for 2012 was estimated at \$316.6 billion [6]; the same factor in the European Union in 2005 amounted to $€ 169$ billion [4], and for the 6 largest economies in Europe in $2014-€ 102.1$ billion [7]. The number of countries which analyze the economic impact of CVD and the publications on this topic is growing [8-11].

Earlier, the analysis of the nationwide economic burden of the CVD was conducted on the basis of data of 2006-2009 years [1]; as the long time has passed since then, morbidity and mortality rates and some aspects of financing medical care have changed, it is advisable to carry out the analysis of the economic burden of CVD under current conditions.

Objectives: to determine the economic burden of the CVD in the RF in 2016, including the direct costs of the health care system and the indirect losses in the economy, caused by a decline in labor productivity.

\section{Material and methods}

This analysis reveals the economic impact of CVD, including direct costs (of health care system and disability benefits payment) and indirect costs in the economy for the year 2016. Economic burden components are shown in Fig. 1.
Сердечно-сосудистые заболевания (СС3) характеризуются значительным социально-экономическим бременем, ложащимся как на систему здравоохранения, так и на экономику в целом [1], и рассматриваются как важный приоритет долгосрочного социально-экономического развития Российской Федерации (РФ) [2]. Ущерб от ССЗ может быть весьма значительным, так как это не только затраты на лечение, но и потери в экономике, связанные с инвалидностью, снижением производительности труда и преждевременной смертностью $[3,4]$. Например, ишемическая болезнь сердца (ИБС) является ведущей причиной инвалидности в Европе, обуславливая 10\% всех лет, прожитых в состоянии инвалидности [5].

Анализ экономического ущерба от заболевания может быть инструментом оценки эффективности расходования ресурсов системы здравоохранения и обоснованием инвестиций в профилактику и лечение для снижения бремени заболеваний, прежде всего, за счет сокращения потерь в экономике. Например, экономический ущерб от ССЗ в США за 2012 г. оценивали в \$316,6 млрд [6]; аналогичный показатель в объединенной Европе в 2005 г. составил €169 млрд [4], а для 6 крупнейших экономик Европы в 2014 г. - €102,1 млрд [7]. Количество стран, которые проводят анализ экономического ущерба от ССЗ и публикаций на эту тему растет [8-11].

Ранее анализ экономического ущерба от ССЗ в масштабах страны проведен на основании данных 2006-2009 гг. [1], но так как с тех пор прошло значительное время, изменились показатели заболеваемости и смертности и некоторые аспекты финансирования медицинской помощи, то целесообразно проведение анализа экономического ущерба от ССЗ в настоящих условиях.

Цель: определить экономический ущерб от ССЗ в РФ в 2016 г., включая прямые затраты системы здравоохранения и непрямые потери в экономике, обусловленные снижением производительности труда.

\section{Материал и методы}

В рамках настоящего анализа определялся экономический ущерб от ССЗ, в том числе - прямые затраты (системы здравоохранения и выплаты пособий по инвалидности) и непрямые потери в экономике на 2016 г. Компоненты экономического ущерба представлены на рис. 1. 


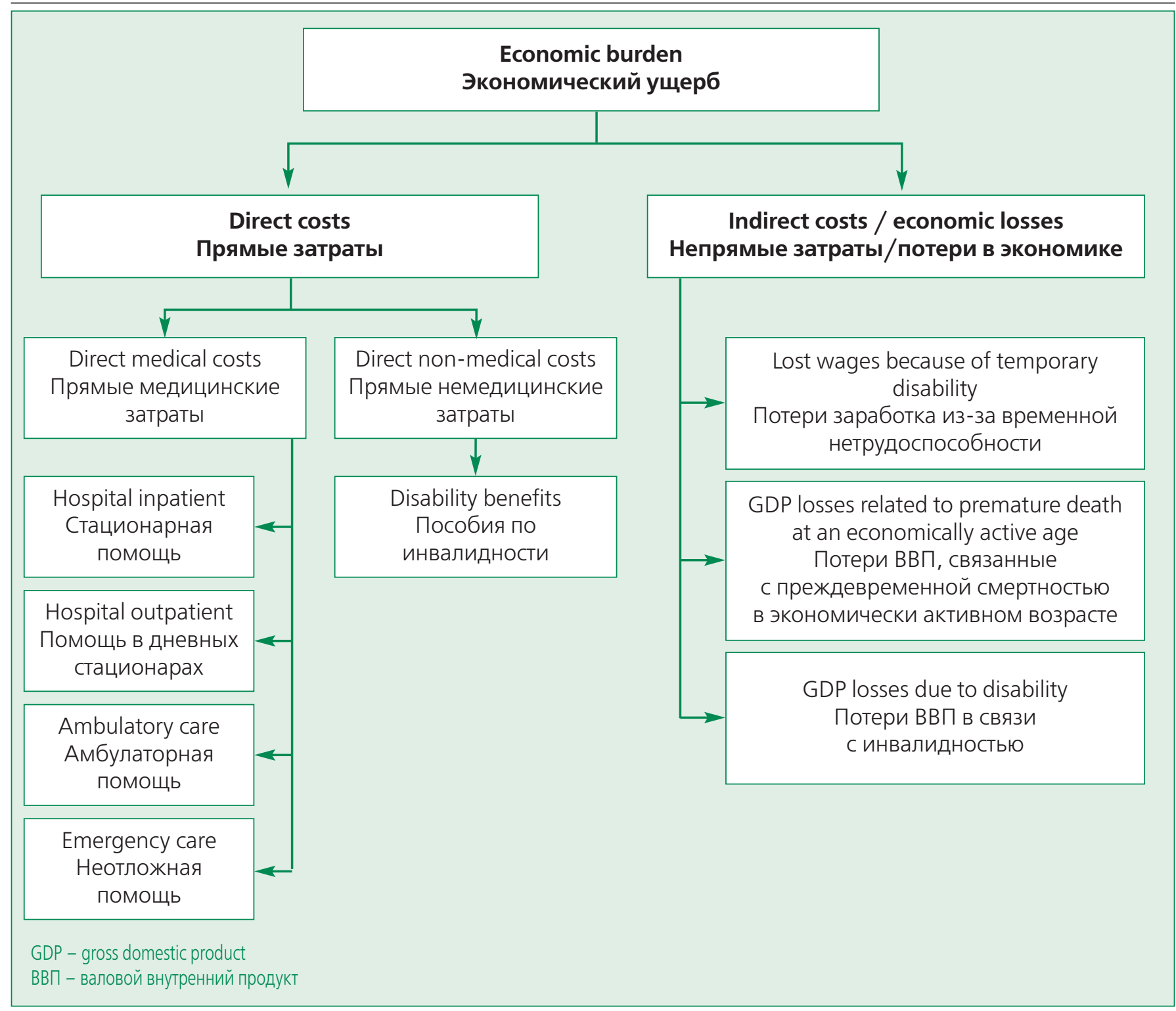

Figure 1. Components of economic burden

Рисунок 1. Компоненты экономического ущерба

The main sources of data for this study were:

- The data of the Federal State Statistics Service (www.gks.ru), including the sex and age structure of the population, age-specific mortality by the International Classification of Diseases (ICD) codes, economic parameters (gross domestic product (GDP), average wages, etc.).

- Data of the Annual forms of Federal statistical observation, including F.14 "Information on the activities of units of a medical institution that provides medical care in hospital settings" (hospitalizations, emergency calls for ambulance (emergency ambulance service - EAS) by codes ICD-10), F.141 "Information on the activities of day hospitals of medical organizations", F.12 "Information on the number of diseases registered in patients living in the area of care of a medical organization" and
Основными источниками данных для настоящего исследования послужили:

- Данные Федеральной службы государственной статистики (www.gks.ru), в том числе, половозрастная структура населения, повозрастная смертность населения по кодам Международной Классификации Болезней (МКБ), экономические параметры (величина валового внутреннего продукта (ВВП), средней заработной платы и др.)

- Данные годовых форм Федерального статистического наблюдения, в том числе ф.14 «Сведения о деятельности подразделений медицинской организации, оказывающих медицинскую помощь в стационарных условиях» (госпитализации, вызовы скорой медицинской помощи (СМП) по кодам МКБ-10), ф.141 «Сведения о деятельности дневных стационаров медицинских организаций», ф.12 «Сведения о числе заболеваний, зарегистрирован- 
F.16-VN "Information on the causes of temporary incapacity for work".

- To determine the cost of outpatient and inpatient medical care, the indicators of the Program of the State Guarantees of free medical care and the corresponding computational clinical and statistical groups of year 2016 were used [12].

- The analysis included statistical data on CVD (ICD code I00-I99), IHD (ICD code I20-I25); myocardial infarction (MI, ICD code 121-I22); cerebrovascular diseases (ICD codes 160-169), stroke (161-163).

Direct costs were understood as direct medical costs for out-patient, inpatient (including day hospital) and EAS care; and under direct non-medical costs we understood the cost of disability benefits.

Direct medical costs were calculated on the basis of the number of hospitalizations, EAS calls and outpatient visits for CVD in 2016 (Forms 12 and 14), using the cost of one treatment/hospitalization under the State Guarantee Program [12]. Tariffs used to calculate the cost of hospitalizations for myocardial infarction and stroke are indicated in Table 1 The volume of disability benefits payments was calculated on the number of disabled persons in each group of CVD [13] and on the amount of disability benefit [14].

Indirect costs (economic losses) included shortage of GDP due to premature mortality and disability in economically active age and loss of earnings due to temporary disability.

Mortality was studied using the WHO mortality database [18] and the data of the RF database on fertility and mortality [19]. We defined the absolute number of deaths (age-specific mortality from a specific cause per 1 million population multiplied by the population size of the corresponding age and sex), and calculated such an indicator as "Potential Years of Life Lost" (PYLL) - the number of years of life not reached in the economically active age due to premature death - by summing up the absolute number of deaths in each age group, multiplied by the number of years lost till 72 years for each age group. Losses associated with premature mortality in economically active age included unproduced GDP due to lost years of life in the relevant age group due to death from CVD, taking into account the employment rate [17]. The future years losses were calculated using the net present value of future losses with a $3 \%$ discount.

The GDP losses due to disability are defined as follows: the number of persons of working age with persistent disability in each of the disability groups. Then the estimated number of unemployed disabled ных у пациентов, проживающих в районе обслуживания медицинской организации» и ф. 16-ВН «Сведения о причинах временной нетрудоспособности».

- Для определения стоимости амбулаторной и стационарной врачебной помощи использованы показатели программы государственных гарантий оказания бесплатной медицинской помощи и соответствующих расчетных клинико-статистических групп на 2016 г. [12].

- В анализ включены статистические данные по ССЗ (код МКБ І00-199), ИБС (код МКБ І20-125); инфаркту миокарда (ИМ; код МКБ І21-122); цереброваскулярным заболеваниям (ЦВ3; коды МКБ 160-169), инсульту (161-163).

Под прямыми затратами понимали прямые медицинские затраты на амбулаторно-поликлиническую, стационарную (включая дневной стационар) и СМП; а под прямыми немедицинскими затратами понимали расходы на выплаты пособий по инвалидности.

Расчеты прямых медицинских затрат производились на основании количества госпитализаций, вызовов СМП и амбулаторных посещений по поводу ССЗ в 2016 г. (формы 12 и 14) с использованием стоимости одного обращения/госпитализации по программе государственных гарантий [12]. Тарифы, использованные для расчета стоимости госпитализаций при ИМ и инсульте, указаны в табл. 1. Объем выплат пособий по инвалидности рассчитывали по количеству инвалидов каждой группы для СС3 [13] и по величине пособия по инвалидности [14].

Непрямые затраты (экономические потери) включали недополучение ВВП вследствие преждевременной смертности и инвалидности в экономически активном возрасте и потери заработка из-за временной нетрудоспособности.

Смертность изучали по базе данных ВОЗ [18] и данным Российской базы данных по рождаемости и смертности [19]. Определяли абсолютное количество летальных исходов (повозрастная смертность от конкретной причины на 1 млн населения, умноженная на численность населения соответствующего возраста и пола), и рассчитывали такой показатель как «потерянные годы потенциальной жизни» (ПГПЖ) - число лет жизни, недожитых в экономически активном возрасте вследствие преждевременной смерти путем суммирования абсолютного числа смертей в каждой возрастной группе с умножением на число лет, недожитых до 72 лет для каждой возрастной группы. Потери, связанные с преждевременной смертностью в экономически активном возрасте, включали непроизведенный ВВП вследствие потерянных лет жизни в соответствующей возрастной группе по причине смерти от ССЗ с учетом коэффициента занятости населения [17]. Потери будущих лет рассчитывали с использованием подхода «net present value/чистой приведенной стоимости» будущих потерь с 3\% дисконтированием.

Потери ВВП из-за инвалидности определены следующим образом: вначале рассчитано число лиц трудоспособ- 
Table 1. Costs indexes included in the analysis

Таблица 1. Показатели стоимости, включенные в анализ

Index / Показатель

Value / Стоимость (\$)

Cost of 1 hospitalization due to CHI under the State Guarantee Program of medical care [12]

Стоимость 1 госпитализации за счет ОМС по Программе государственных гарантий медицинской помощи [12]

$22,815.3$

Coefficient of relative cost-intensity of DRG of diseases for cardiology

Коэффициент относительной затратоемкости КСГ заболеваний для кардиологии

Coefficient of relative cost-intensity of DRG of unstable angina, MI, pulmonary embolism (level 2 [15])

Коэффициент относительной затратоемкости КСГ для нестабильной стенокардии, ИМ, легочной эмболии (уровень 2 [15]

2.81

Coefficient of relative cost-intensity of DRG of cerebral infarction (level 2)

Коэффициент относительной затратоемкости КСГ для инфаркт мозга (уровень 2)

3.12

The cost of EAS calling under the State Guarantees Program in 2016 [12]

Стоимость вызова СМП по Программе государственных гарантий в 2016 г. [12]

The cost of 1 case of treatment in a day hospital [12]

Стоимость 1 случая лечения в условиях дневных стационаров [12]

The cost of 1 outpatient treatment under the State Guarantee Program of medical care, taking into account the multiplicity of visits within the

same outpatient treatment and the correction coefficient for the specialty of cardiology [12]

Стоимость 1 амбулаторного обращения по Программе государственных гарантий медицинской помощи, сучетом кратности посещение

в рамках одного амбулаторного обращения и поправочного коэффициента по специальности кардиология [12]

$1,005.0$

The average monthly calculation of disability benefits in 2016 according to the data of the Pension Fund (group 1 disability) [16]

Среднемесячная расчетная величина пособий по инвалидности в 2016 г. по данным Пенсионного фонда (1 группа инвалидности) [16]

The average monthly calculation of disability benefits in 2016 according to the data of the Pension Fund (2 disability group) [16]

Среднемесячная расчетная величина пособий по инвалидности в 2016 г. по данным Пенсионного фонда составила (2 группа инвалидности) [16]

The average monthly calculation of disability benefits in 2016, according to the data of the Pension Fund (group 3 disability) [16]

Среднемесячная расчетная величина пособий по инвалидности в 2016 г. по данным Пенсионного фонда составила (3 группа инвалидности) [16]

GDP per capita in 2016 [13]

ВВП на душу населения в 2016 г. [13]

$586,630.0$

GDP per 1 employed in 2016 (calculated rate)] [13,17]

ВВП на 1 занятого в 2016 г. (расчетный показатель) [13,17]

$1,188,563.11$

Average daily wage in the RF in 2016 (calculated rate) [17]

Средняя дневная заработная плата в РФ в 2016 г. (расчетный показатель) [17]

The average monthly nominal accrued wages of workers in the economy of the RF in 2016 [17]

Среднемесячная номинальная начисленная заработная плата работников в целом по экономике РФ в 2016 г. [17]

CHI - compulsory health insurance, DRG - diagnosis-related group, GDP - gross domestic product, RF - the Russian Federation, IM - myocardial infarction, EAS - emergency ambulance service

OMC - обязательное медицинское страхование, КСГ - клиникостатистическая группа, ВВП - валовой внутренний продукт, РФ - Российская Федерация, ИМ - инфаркт миокарда,

СМП - скорая медицинская помощь

Table 2. Potential years of life lost in economically active age (up to 72 years) due to CVD mortality

Таблица 2. Потерянные годы потенциальной жизни в экономически активном возрасте (до 72 лет) вследствие смерти от СС3

\begin{tabular}{lccc}
\hline Cause / Причина & Male / Мужчины & Female / Женщины & All / Bce \\
\hline CVD / СС3 & $3,302,660$ & $1,225,478$ & $4,528,138$ \\
\hline IHD / ИБC & $1,602,392$ & 489,617 & $2,092,009$ \\
\hline MI / ИМ & 290,071 & 75,193 & 365,265 \\
\hline Cerebrovascular disease / ЦВ3 & 650,320 & 331,815 & 982,135 \\
\hline Stroke / Инсульт & 531,848 & 268,526 & 800,374 \\
\hline
\end{tabular}

CVD - cardiovascular disease, IHD - ischemic heart disease, $\mathrm{Ml}$ - myocardial infarction

ССЗ - сердечно-сосудистые заболевания, ИБС - ишемическая болезнь сердца, ИМ - инфаркт миокарда, ЦВЗ - цереброваскулярные заболевания

in working age was multiplied by GDP per capita [20]. Indirect costs due to temporary disability due to CVD were considered as payments of wages for days of incapacity for work multiplied by the number of ного возраста со стойкой утратой трудоспособности в каждой из групп инвалидности. Затем расчетное число неработающих инвалидов трудоспособного возраста умножено на ВВП на душу населения [20]. Непрямые за- 
Table 3. Economic burden of cardiovascular diseases in the Russian Federation in 2016

Таблица 3. Экономический ущерб от сердечно-сосудистых заболеваний в Российской Федерации в 2016 г.

\begin{tabular}{|c|c|c|c|c|c|}
\hline $\begin{array}{l}\text { Component of burden } \\
\text { Компонент ущерба }\end{array}$ & $\begin{array}{l}\text { CVD } \\
\text { CC3 }\end{array}$ & $\begin{array}{l}\text { IHD } \\
\text { ИБC }\end{array}$ & $\begin{array}{l}\text { MI } \\
\text { ИM }\end{array}$ & $\begin{array}{l}\text { Cerebrovascular diseas } \\
\text { ЦВВ3 }\end{array}$ & $\begin{array}{l}\text { se Stroke } \\
\text { Инсульт }\end{array}$ \\
\hline \multicolumn{6}{|l|}{ Direct costs (₹) / Прямые затраты(尹) } \\
\hline In-patient care / Стационарная помощь & $171,934,542,847$ & $80,705,876,656$ & $45,313,596,900$ & $46,973,007,431 \quad 2$ & $29,404,998,278$ \\
\hline Day hospital / Дневной стационар & $27,393,126,570$ & $6,168,671,681$ & $151,209,639$ & $5,658,049,231$ & $334,302,998$ \\
\hline Costs of EAS / Затраты на СMП & $2,726,950,292$ & $1,090,557,809$ & $261,980,230$ & $770,071,574$ & $543,213,123$ \\
\hline Out-patient care / Амбулаторная помощь & $35,453,585,357$ & $7,983,810,370$ & $195,703,248$ & $7,322,936,681$ & $432,672,037$ \\
\hline Direct medical costs, total / Прямые медицинские затраты, всего & $237,508,205,065$ & $95,948,916,515$ & $45,922,490,017$ & $60,724,064,916 \quad 3$ & $30,715,186,436$ \\
\hline Costs of disability benefits / Затраты на пособие по инвалидности & $3,082,434,814$ & $694,135,016$ & $17,014,993$ & $636,676,791$ & $37,617,729$ \\
\hline Direct costs, total / Прямые затраты, всего & $240,590,639,880$ & $96,643,051,531$ & $45,939,505,010$ & $61,360,741,708 \quad 3$ & $30,752,804,165$ \\
\hline \multicolumn{6}{|l|}{ Economy indirect losses (₹) / Непрямые потери в экономике (₹) } \\
\hline \multicolumn{6}{|l|}{ GDP losses due to premature mortality } \\
\hline GDP losses due to disability / Потери ВВП от инвалидности & $204,918,238,334$ & $46,145,639,141$ & $1,131,145,536$ & $42,325,854,182$ & $2,500,801,844$ \\
\hline Losses due to temporary disability / Потери от BУT & $44,721,648,264$ & $11,874,103,148$ & $246,862,813$ & $9,958,734,951$ & $545,778,557$ \\
\hline Economy indirect losses, total / Непрямые потери в экономике, всего & $2,502,775,099,406$ & $991,036,104,392$ & $167,308,552,063$ & $3 \quad 500,721,753,458 \quad 3$ & $393,551,510,613$ \\
\hline \multicolumn{6}{|l|}{ Total economic burden (₹) / Всего экономический ущерб (₹) } \\
\hline Total burden and expenses / Всего потерь и затрат & $2,743,365,739,286$ & $1,087,679,155,923$ & $213,248,057,073$ & $562,082,495,165$ & $424,304,314,777$ \\
\hline$\%$ of GDP / \% от ВBП & $3.2 \%$ & $1.3 \%$ & $0.2 \%$ & $0.6 \%$ & $0.5 \%$ \\
\hline In billions of $\mathrm{P} /$ В млрд $\mathrm{f}$ & $2,743.4$ & $1,087.7$ & 213,2 & 562.1 & 424.3 \\
\hline \multicolumn{6}{|c|}{ CVD - cardiovascular diseases, IHD - ischemic heart disease, MI - myocardial infarction, EAS - emergency ambulance service, GDP - gross domestic product } \\
\hline \multicolumn{6}{|c|}{$\begin{array}{l}\text { ССЗ - сердечно-сосудистые заболевания, ИБС - ишемическая болезнь сердца, ИМ - инфаркт миокарда, ЦВЗ - цереброваскулярные заболевания, СМП - скорая медицинская помощь, } \\
\text { ВВП - валовой внутренний продукт, ВУТ - временная утрата трудоспособности }\end{array}$} \\
\hline
\end{tabular}

days of temporary disability according to Form 16-VN for 2016

Statistical analysis. Calculations using descriptive statistics methods were performed in MS Excel 10.0 (Microsoft, USA).

\section{Results}

Table 2 presents an important intermediate indicator for determining the economic impact of CVD PYLL due to premature death from CVD. So only during 1 year there are lost due to CVD 4.5 million years of potential life in economically active age, mainly at the expense of men as a whole ( 3.3 million PYLL), and of certain analyzed diseases. Almost $50 \%$ of male's PYLL are caused by IHD, while the share of cerebrovascular disease in the loss of years of economically active life is twice lower.

Table 3 presents all the components of the economic burden of CVD in general and of certain disease groups. In general, the economic impact of CVD in the RF in 2016 amounted to 2.7 trillion $¥$, which is equivalent to $3.2 \%$ of GDP for this year. In the structure of economic burden of all diseases of the circulatory system, IHD retains the first place - more than 1 trillion P, which is $1.3 \%$ of GDP; over 560 bil- траты из-за временной нетрудоспособности вследствие ССЗ считали как выплаты заработной платы за дни нетрудоспособности, умноженные на количество дней временной нетрудоспособности по данным ф. 16-ВН за 2016 г.

Статистический анализ. Расчеты с использованием методов описательной статистики проводили в программе MS Excel 10.0 (Microsoft, США).

\section{Результаты}

В табл. 2 представлен важный промежуточный показатель определения экономического ущерба от ССЗ - ПГПж вследствие преждевременной смерти от ССЗ. Так, только за 1 год вследствие СС3 теряется 4,5 млн лет потенциальной жизни в экономически активном возрасте, преимущественно, за счет мужчин в целом (3,3 млн ПГПЖ) и по отдельным анализируемым заболеваниям. Почти 50\% ПГПЖ мужчин обусловлены ИБС, в то время как доля ЦВЗ в потере лет экономически активной жизни в два раза меньше.

В табл. 3 представлены все компоненты экономического ущерба от ССЗ в целом, и для отдельных групп заболеваний. В целом экономический ущерб от ССЗ в РФ в 2016 г. составил 2,7 трлн Р, что эквивалентно 3,2\% ВВП за этот год. В структуре ущерба среди всех болезней системы кровообращения ИБС удерживает первое место - свыше 


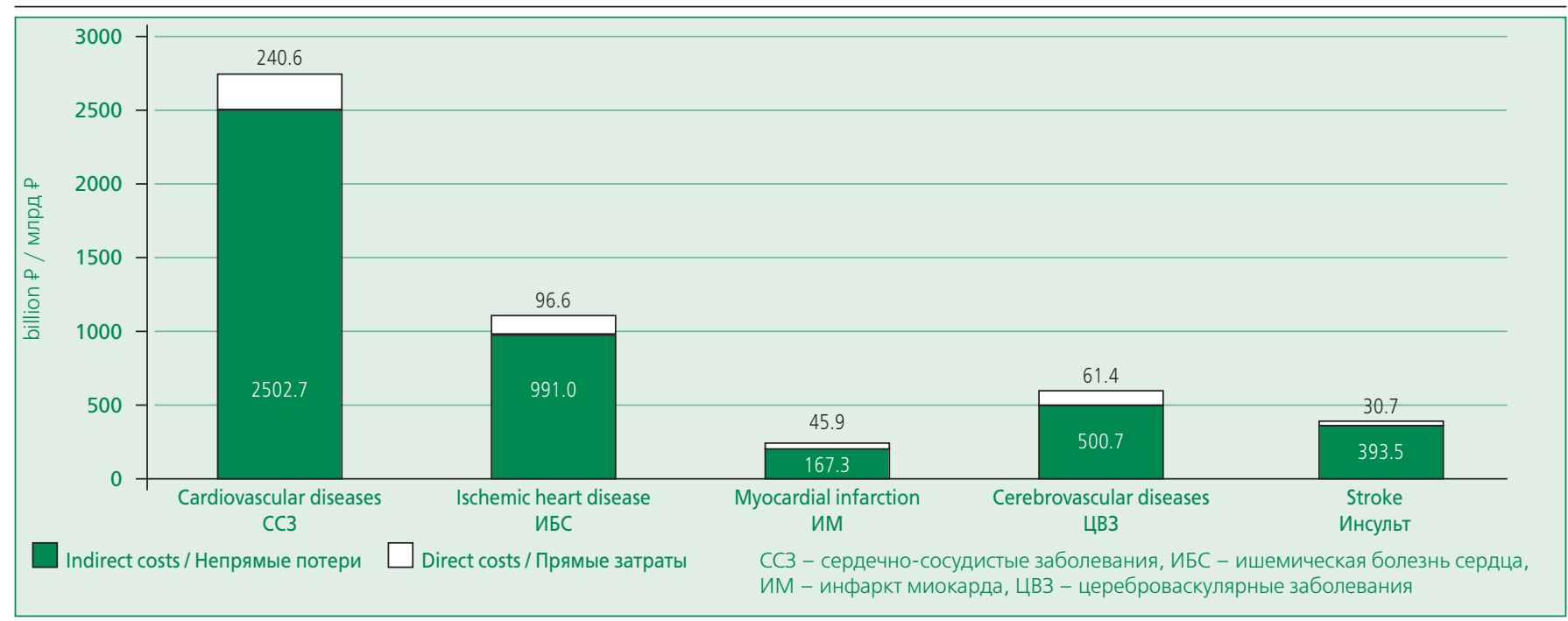

Figure 2. The structure of economic burden of cardiovascular diseases in total in 2016 and individual disease groups (billion P)

Рисунок 2. Структура экономического ущерба от ССЗ в целом в 2016 г. и от дельных групп заболеваний (млрд Р)

lion $\mathrm{P}$ are accounted for cerebrovascular diseases; over 424 billion $\mathrm{P}$ and 213.2 billion $\mathrm{P}$ - for stroke and myocardial infarction, respectively.

The structure of the economic impact of CVD in 2016 in general and in certain groups of diseases is presented in Figure 2. In the structure of economic burden, direct costs amounted to only $8.1 \%$ and 220 billion $\mathrm{F}$, while losses in the economy accounted for $91.9 \%$ of total burden ( 2.5 trillion $\mathrm{P}$ ). For individual diseases, the main burden is also determined by indirect losses in the economy, the exception is myocardial infarction, in which direct losses account for $21.5 \%$

In the total economic impact of CVD, 39.6\% are determined by IHD, the fifth part - cerebrovascular diseases (Figure 3).

\section{Discussion}

CVD are the cause of the enormous costs of health care systems of states around the world. Economic losses associated with the decrease in labor productivity due to premature morbidity, disability and mortality due to this group of diseases are also significant [2]. CVD according to a systematic review by Muka T. et al. determine the greatest financial burden on the health care system [21] among all disease groups. At the same time, it is important to take into account that the negative economic effect of CVD is caused not only by current direct costs and GDP losses, but also by the slowdown of the expected economic growth [22].

In this study the analysis of the economic impact of CVD in the RF in 2016 was carried out using a
1 трлн Р , что составляет 1,3\% ВВП, свыше 560 млрд Р приходится на ЦВ3, свыше 424 млрд ₹ и 213,2 млрд ₹ - на инсульты и инфаркты, соответственно.

Структура экономического ущерба от ССЗ в 2016 г. в целом и в отдельных группах заболеваний представлена на рис. 2. В структуре ущерба прямые затраты составили всего лишь 8,1\% и 220 млрд Р, в то время как потери в экономике определили 91,9\% совокупного ущерба (2,5 трлн Р). По отдельным заболеваниям основной ущерб также определяется непрямыми потерями в экономике, за исключением инфаркта миокарда, где на прямые потери приходится 21,5\%.

В совокупном ущербе от ССЗ 39,6\% составляет ИБС, пятую часть - ЦВЗ (рис. 3).

\section{Обсуждение}

ССЗ являются причиной колоссальных затрат систем здравоохранения государств по всему миру. Значительны также и экономические потери, связанные со снижением производительности труда по причине преждевременной заболеваемости, инвалидизации и смертности населения этой группы заболеваний [2]. По данным систематического обзора Muka Т. и соавт. СС3 определяют наибольшую финансовую нагрузку на систему здравоохранения [21] среди всех групп заболеваний, при этом важно учитывать, что негативный экономический эффект от ССЗ обусловлен не только текущими прямыми затратами и потерями ВВП, но и торможением ожидаемого роста экономики [22].

В настоящем исследовании проведен анализ экономического ущерба от ССЗ в РФ в 2016 г. с использованием распространенного подхода с изучением как прямых затрат системы здравоохранения, так и потерь в экономике, обусловленных снижением производительности труда [7], 


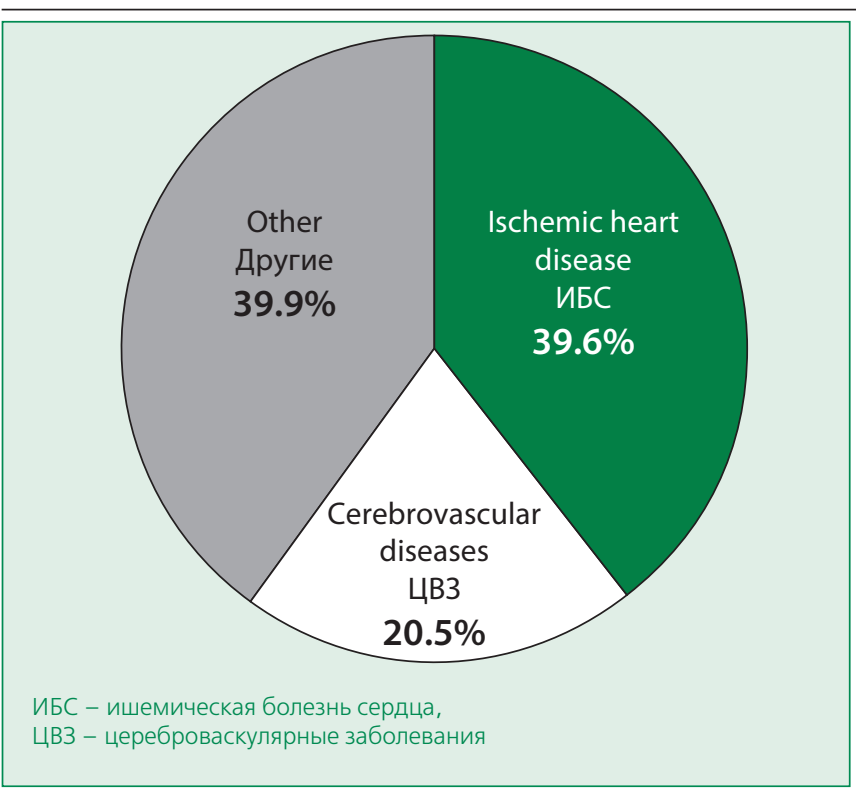

Figure 3. Structure of economic burden of CVD by disease groups (\%)

Рисунок 3. Структура экономического ущерба от ССЗ по группам заболеваний (\%)

common approach with the study of both the direct costs of the health care system and the losses in the economy caused by the decline in labor productivity [7]; although the number of components included in the analysis may vary depending on the methodology and availability of data.

Economic burden of the CVD in the RF in 2016 amounted to 2.7 trillion $P$, which is equivalent to $3.2 \%$ of the RF GDP in 2016. The previous analysis showed that in 2009 the economic burden of the CVD was 1.1 trillion $₹$ or $2.8 \%$ of GDP in the analyzed year. The methodology of this study was somewhat different from the analysis performed in 2009 [1]. So, in 2009 the costs of the outpatient medical treatment were included in the analysis as the part of direct costs, and in this study they were not included (due to the lack of data for 2016, and also because, with the exception of the proportion of people on concessional medicines, this is not the health care system's costs, but the personal funds of patients). Also in 2009, the costs for percutaneous coronary interventions $(\mathrm{PCI})$ in acute coronary syndrome were calculated separately, because at that time they were considered as high-tech medical care group; and in 2016, the PCI was already included into the Compulsory Health Insurance (CHI) program for $\mathrm{MI}$, therefore, these costs were not calculated separately. In 2016, the methodology for determining economic losses from premature mortality changed: PYLL was calculated to the upper limit of the economically active age ( 72 years), considering the employment ratio of each 5 -year age group, and in 2009 - to the working age limit. At the same time, in 2016 the approach of calculating the net present value of future losses was applied. These differences in methodology determined a somewhat larger хотя количество компонентов, включенных в анализ, может варьироваться в зависимости от методологии и доступности данных.

Экономический ущерб от ССЗ в РФ в 2016 г. составил 2,7 трлн Р, что эквивалентно 3,2\% ВВП РФ в 2016 г. Ранее проведенный анализ показал, что в 2009 г. экономический ущерб от ССЗ составил 1,1 трлн Р, или 2,8\% ВВП анализируемого года. Методология настоящего исследования несколько отличалась от анализа, выполненного в 2009 г. [1]. Так, в 2009 г. затраты на медикаментозную терапию на амбулаторном этапе включали в анализ в составе прямых затрат, а в настоящем исследовании - нет (из-за отсутствия данных за 2016 г., а также из-за того, что за исключением доли лиц, находящихся на льготном лекарственном обеспечении, это затраты не системы здравоохранения, а личные средства пациентов). Также в 2009 г. отдельно учитывали затраты на чрезкожные коронарные вмешательства (ЧКВ) при остром коронарном синдроме, которые на тот период оплачивались по высокотехнологичной медицинской помощи (ВМП); а в 2016 г. ЧКВ уже включены в тариф обязательного медицинского страхования при ИМ, поэтому отдельно эти затраты на рассчитывали. В 2016 г. несколько изменилась методология определения экономических потерь от преждевременной смертности: ПГПЖ рассчитывали до верхней границы экономически активного возраста ( 72 года) с учетом коэффициента занятости населения в каждой 5-летней возрастной группе, а в 2009 г. - до границы трудоспособного возраста. В то же время в 2016 г. использован подход расчета чистой приведенной стоимости будущих потерь. Эти различия в методологии определили несколько бо̀льшую долю потерь в экономике в 2016 г. по сравнению с 2009 г. Однако, несмотря на некоторые методологические различия, результаты анализа 2009 г. и 2016 г. могут быть в целом сравнены между собой. На основании этого сопоставления можно сделать вывод о том, что экономический 
share of economic losses in 2016 compared to 2009. However, despite some methodological differences, the results of the analysis of the years 2009 and 2016 can be compared in general. Based on this comparison, we can make the conclusion that the economic impact of CVD in the RF for 7 years has grown, which is expected and is due to both the growth of tariffs for medical assistance and GDP growth, despite the decline in CVD mortality over the years. The burden of CVD to GDP in 2009 and 2016 is similar $~ 3 \%$.

The economic impact of CVD in the USA in 2012, according to Mozaffarian D. et al. amounted to $\$ 316.6$ billion, in which almost half - the direct costs of the health care system ( $\$ 193.1$ billion). The analysis also included the costs of medicines, medical home care; the economic losses due to premature deaths amounted to $\$ 123.5$ billion, so their share in the burden structure was less than the share of direct costs of the health care [6]. In India, which by the size of the population is steadily catching up with China, the direct costs of the health care system for the CVD in 2004 amounted to only $\$ 10.2$ billion. [10]. In India in 2015 indirect losses in the economy because of CVD due to the decline in labor productivity amounted to $\$ 1.96$ billion. [23]. In Serbia, in 2009 , the volume of the economic losses due to the CVD was $€ 400$ million and $1.8 \%$ of GDP [24].

In one of the latest studies conducted in 6 countries in Europe with the largest economies (France, Germany, Italy, Spain, Sweden and the United Kingdom), the economic impact of CVD amounted to $€ 102.1$ billion in 2014, which is comparable to the annual GDP of a country like Hungary. [7]. The direct costs of the health care system amounted to $€ 81.1$ billion ( $70-80 \%$ of the total burden in the analyzed countries). The second largest component was the losses due to premature mortality (€19.6 billion); indirect economic losses associated with the incidence of diseases amounted to $€ 1.4$ billion.

In the previous study carried out throughout the European Union in 2004, the total economic loss amounted to $€ 169$ billion, the share of health care system costs was $61 \%$ [4].

Thus, in the RF the structure of the economic burden of CVD is different from the results of studies carried out in Western countries. In our country the losses in the economy predominate, and the share of the health system costs is substantially less. In the European countries and in the USA the health care system costs predominate $[6,7]$. These differences may arise partly due to a difference in methodology, but, at the same time, there are certainly real differences in the structure of economic burden due to unequal ущерб от ССЗ в РФ за 7 лет вырос, что ожидаемо и обусловлено как ростом тарифов на медицинскую помощь, так и ростом ВВП, несмотря на наблюдавшееся за эти годы снижение смертности от ССЗ. Сопоставление с ВВП ущерба от ССЗ 2009 г. и 2016 г. дает схожий результат 3\%.

Экономический ущерб от ССЗ в США в 2012 г. по данным Mozaffarian D. и соавт. составил \$316,6 млрд, в котором почти половина - прямые затраты системы здравоохранения $(\$ 193,1$ млрд). В анализ были включены также затраты на медикаментозные препараты, медицинское обслуживание на дому, а потери в экономике в связи с преждевременной смертностью составили $\$ 123,5$ млрд, т.е. их доля в структуре ущерба была меньше, чем доля прямых затрат системы здравоохранения [6]. В Индии, которая по численности населения неуклонно догоняет Китай, прямые затраты системы здравоохранения на СС3 в 2004 г. составили всего \$10,2 млрд [10]. Непрямые потери в экономике от ССЗ вследствие снижения производительности труда в Индии в 2015 г. составили \$1,96 млрд [23]. В Сербии величина экономического ущерба от ССЗ составила $€ 400$ млн и $1,8 \%$ ВВП в 2009 г. [24].

В одном из последних исследований, проведенном в 6 странах Европы с наибольшими экономиками (Франция, Германия, Италия, Испания, Швеция и Великобритания), экономический ущерб от ССЗ составил в 2014 г. €102,1 млрд, что сопоставимо с годовым ВВП такой страны, как Венгрия [7]. Прямые затраты системы здравоохранения составили €81,1 млрд (70-80\% всего ущерба по анализируемым странам). Вторым по объему компонентом оказались потери в связи с преждевременной смертностью (€19,6 млрд), непрямые потери в экономике, связанные с заболеваемостью, составили €1,4 млрд.

В предыдущем исследовании, выполненном во всем Европейском регионе в 2004 г., общий экономический ущерб составил €169 млрд, доля затрат системы здравоохранения - 61\% [4].

Таким образом, структура экономического ущерба от ССЗ по результатам исследований, выполненных в РФ, отличается таковой по результатам исследований, выполненных в западных странах. В нашей стране преобладают потери в экономике, а доля затрат системы здравоохранения существенно меньше. В Европейских странах и США преобладают затраты системы здравоохранения $[6,7]$. Эти различия могут быть частично обусловлены разницей в методологии, но, вместе с тем, безусловно - реально существующими отличиями в структуре ущерба вследствие неодинаковых уровней преждевременной смертности и финансирования системы здравоохранения. В структуре экономического ущерба от ССЗ в РФ по группам заболеваний преобладают затраты, ассоциированные с ИБС (40\%). Аналогичные данные получены в исследованиях в Европейском регионе и Великобритании $[4,8,25]$ 
levels of premature mortality and health care system financing. In the structure of the economic losses from CVD in the RF, the IHD associated costs (40\%) prevail among the groups of diseases. Similar results were obtained in studies in Europe and the United Kingdom. $[4,8,25]$

\section{Limitations of the study}

1. The analysis does not include all possible components of direct costs (costs of the outpatient drug treatment) and losses in the economy (for example, presenteeism - the decline in labor productivity due to illness during the presence at work).

2. Some of the economic burden components are accounted for partially (calls to the EAS have been considered only in the part that resulted in hospitalization (Form 14), disability-related losses were considered only in terms of primary disability).

\section{Conclusion}

In the RF in 2016 the economic burden of CVD amounted to 2.7 trillion $P$, which is equivalent to $3.2 \%$ of GDP in 2016. The structure of the economic burden (over $90 \%$ ) is dominated by economic losses caused by premature mortality of people of economically active age.

The data confirming the significant economic burden is a weighty argument in favor of increasing the investment in the prevention and treatment of CVD. Such investments will have a significant economic effect in the long term and will contribute not only to improving the health of the population, but also to economic growth.

Disclosures. All authors have not disclosed potential conflicts of interest regarding the content of this paper.

\section{Ограничения исследования}

1. В анализ включены не все возможные компоненты прямых затрат (затраты на медикаментозную терапию на амбулаторном этапе) и потерь в экономике (например, презентеизм - снижение производительности труда вследствие заболевания при присутствии на рабочем месте).

2. Часть компонентов ущерба учтены частично (вызовы СМП учтены только те, которые завершились госпитализацией (форма 14), потери в связи с инвалидностью учтены только в части первичного выхода на инвалидность).

\section{Заключение}

Экономический ущерб от ССЗ в РФ в 2016 г. составил 2,7 трлн Р , что эквивалентно 3,2\% ВВП 2016 г. В структуре ущерба (свыше 90\%) преобладают потери в экономике, обусловленные преждевременной смертностью лиц экономически активного возраста.

Данные о столь значимом экономическом ущербе - весомый аргумент в пользу увеличения инвестиций в профилактику и лечение ССЗ. Такие инвестиции окажут значимый экономический эффект в долгосрочном периоде и будут способствовать не только улучшению здоровья населения, но и экономическому росту.

Конфликт интересов. Все авторы заявляют об отсутствии потенциального конфликта интересов, требующего раскрытия в данной статье. 


\section{References / Литература}

1. Oganov R.G., Kontsevaya A.V., Kalinina A.M. State Economic Burden of Cardiovascular Diseases in the Russian Federation. Cardiovascular Therapy and Prevention. 2011;10(4):4-9. (In Russ.) [Оганов Р.Г., Концевая А.В., Калинина А.М. Экономический ущерб от сердечно-сосудистых заболеваний в Российской Федерации. Кардиоваскулярная терапия и профилактика. 2011;10(4):4-9]

2. Saygitov R.T., Chulok A.A. Cardiovascular diseases in the context of Russia's long-term socio-economic development priorities. Annals of the Russian academy of medical sciences 2015;70(3):286-99. (In Russ.) [Сайгитов P.T., Чулок А.А. Сердечно-сосудистые заболевания в контексте социально-экономических приоритетов долгосрочного развития россии. Вестник Российской академии медицинских наук. 2015;70(3):286-99]. doi:10.15690/vramn.v70i3.13243.

3. Virtanen M., Ervasti J., Mittendorfer-Rutz E., Lallukka T. et al. Work disability before and after a major cardiovascular event: A ten-year study using nationwide medical and insurance registers. Scientific Reports. 2017;7(1):1142. doi:10.1038/s41598-017-01216-2.

4. Leal J., Luengo-Fernández R., Gray A. et al. Economic burden of cardiovascular diseases in the enlarged European Union. Eur Heart J. 2006;27(13):1610-1619. doi:10.1093/eurheartj/ehi733.

5. National Institute for Health and Clinical Excellence. Statins for the prevention of cardiovascular events. Available at: https://www.nice.org.uk/guidance/ta94. Checked by Mar 24, 2018.

6. Mozaffarian D, Benjamin E.J., Go A.S. et al. Heart disease and stroke statistics-2016 update a report from the American Heart Association. Circulation. 2016;133(4):38-360. doi:10.1161/CIR. 0000000000000350 .

7. Centre for Economics and Business Research. The economic cost of cardiovascular disease from 20142020 in six European economies. London: CERB; 2014

8. Tuppin P, Rivière $S$, Rigault $A$. et al. Prevalence and economic burden of cardiovascular diseases in France in 2013 according to the national health insurance scheme database. Archives of Cardiovascular Diseases. 2016;109(6-7):399-411. doi:10.1016/j.acvd.2016.01.011.

9. Yang L, Wu M, Cui B, Xu J. Economic burden of cardiovascular diseases in China. Expert Review of Pharmacoeconomics and Outcomes Research. 2008;8(4):349-356. doi:10.1586/14737167. 8.4.349

10. Srivastava A., Mohanty S.K. Age and Sex Pattern of Cardiovascular Mortality, Hospitalisation and Associated Cost in India. PLoS One. 2013;8(5):e62134. doi:10.1371/journal.pone.0062134.

11. Walker I.F., Garbe F., Wright J. et al. The Economic Costs of Cardiovascular Disease, Diabetes Mellitus, and Associated Complications in South Asia: A Systematic Review. Value in Health Regional Issues. 2018;15:12-26. doi: 10.1016/j.vhri.2017.05.003.

12. Government Decision № 1382 of 19 December 2015 «On the Programme of State guarantees for providing citizens of the Russian Federation with free medical care for 2016\%. Available at: http://www.consultant.ru/document/cons_doc_LAW_191018/. Checked by Feb 08, 2018. (In Russ.) [Постановление Правительства РФ от 19 декабря 2015 г. № 1382 «О Программе государственных гарантий бесплатного оказания гражданам медицинской помощи на 2016»]. Доступно на: http://www.consultant.ru/document/cons_doc_LAW_191018/. Проверено 08.02.2018].

13. Federal State Statistics Service. Public Health in Russia. 2017: Statistical Bulletin. M.: Rosstat; 2017. (In Russ.) [Демографический ежегодник России. 2017: Статистический сборник. М.: Росстат; 2017].

14. Government Decision N 220 of 22 March 2014 "On the adoption of the indexation factor of social pension since 1 April 2014". Available at: http://base.garant.ru/70622990/\#ixzz54L3z5RIz. Checked by: Jan 16, 2018. (In Russ.) [Постановление Правительства РФ от 22 марта 2014 г. N 220 «Об утверждении коэффициента индексации с 1 апреля 2014 г. социальных пенсий». Доступно на:http://base.garant.ru/70622990/\#ixzz54L3z5RIz. Проверено: 16.01.2018].

\section{About the Authors:}

Anna V. Kontsevaya - MD, PhD, Deputy Director for Scientific and Analytical Work, National Medical Research Center for Preventive Medicine

Oxana M. Drapkina - MD, PhD, Professor, Corresponding Member of the Russian Academy of Science, Director of National Medical Research Center for Preventive Medicine

Yulia A. Balanova - MD, PhD, Leading Researcher, Laboratory of Economic Analysis of Epidemiological Research and Preventive Technologies, Department of Epidemiology of Chronic Non-Comunicable Diseases, National Medical Research Center for Preventive Medicine Asia E. Imaeva - MD, PhD, Senior Researcher, Department of Epidemiology of Chronic Non-Comunicable Diseases, National Medical Research Center for Preventive Medicine

Evgenia I. Suvorova - Junior Researcher, Laboratory of Economic Analysis of Epidemiological Research and Preventive Technologies, Department of Epidemiology of Chronic Non-Comunicable Diseases, National Medical Research Center for Preventive Medicine

Mihail B. Khudyakov - Leading Engineer, Laboratory of Economic Analysis of Epidemiological Research and Preventive Technologies, Department of Epidemiology of Chronic Non-Comunicable Diseases, National Medical Research Center for Preventive Medicine
15. Letter No. 11-7 / 10 / 2-8080 of the Ministry of Health of the Russian Federation, ФФОМС № 13572 / 26-2 / and on 21.11.2017 "On methodological recommendations on how to pay for medical care from the means of compulsory medical insurance". Available at:http://www.consultant.ru/ document/cons_doc_LAW_283654/. Checked by: Jan 16, 2018. (In Russ.) [Письмо Минздрава России № 11-7/10/2-8080, ФФОМС № 13572/26-2/и от 21.11.2017 «О методических рекомендациях по способам оплаты медицинской помощи за счет средств обязательного медицинского страхования». Доступно на:http://www.consultant.ru/document/cons_doc_LAW_ 283654/. Проверено: 16.01.2018].

16. The average size of pensions for disabled persons registered in the system of the Russian Federation pension fund. Available at: http://www.gks.ru/wps/wcm/connect/rosstat_main/rosstat/ru/statistics/population/disabilities/\#. Checked by: Jan 16, 2018. (In Russ.) [Средний размер назначенных пенсий инвалидов, состоящих на учете в системе пенсионного фонда Российской Федерации (по состоянию на 1 января)]. Доступно на:http://www.gks.ru/wps/wcm/connect/ rosstat_main/rosstat/ru/statistics/population/disabilities/\# Дата последнего обновления: 14.09.2017. Проверено: 16.01.2018].

17. Statistical Bulletin Labor and Employment in Russia. Moscow: Rosstat; 2017. (In Russ.) Труд и занятость в России. 2017: Статистический сборник. М.: Росстат; 2017].

18. WHO. Mortality Database 2014. Available at: http://www.who.int/healthinfo/statistics/ mortality_rawdata/en/. Checked by Jan 10, 2018.

19. Russian database on fertility and mortality. Available at: $h$ http://demogr.nes.ru/ru/demogr_indicat/ data_description. Checked by: Jan 16, 2018. (In Russ.) [Российская база данных по рождаемости и смертности (РосБРиС). Доступно на:http://demogr.nes.ru/ru/demogr_indicat/data_description. Проверено: 16.01.2018

20. Government Decision №192/323H/45H/113 of 10 April 2012 "On the approval of the methodology for calculating economic losses from mortality, morbidity and disability of the population". Available at:http://www.consultant.ru/document/cons doc LAW 129302/. Checked by: Jan 16, 2018. (In Russ.) [Приказ Министерства экономического развития РФ, Министерства здравоохранения и социального развития РФ, Минфина РФ и Федеральной службы государственной статистики от 10 апреля 2012 г. №192/323н/45н/113 «Об утверждении Методологии расчета экономических потерь от смертности, заболеваемости и инвалидизации населения». Доступно на:http://www.consultant.ru/document/cons_doc_LAW_129302/. Проверено: 16.01.2018]

21. Muka T., Imo D., Jaspers L. et al. The global impact of non-communicable diseases on healthcare spending and national income: a systematic review. European Journal of Epidemiology. 2015;30(4):251-77. doi:10.1007/s10654-014-9984-2.

22. Arah O.A., Westert G.P., Delnoij D.M. et al. Health system outcomes and determinants amenable to public health in industrialized countries: A pooled, cross-sectional time series analysis. BMC Public Health. 2005;5(81):1-10. doi:10.1186/1471-2458-5-81.

23. Abegunde D.O., Mathers C.D., Adam T. et al. The burden and costs of chronic diseases in low-income and middle-income countries. Lancet. 2007;370(9603):1929-38. doi:10.1016/501406736(07)61696-1.

24. Lakic D., Tasic L., Kos M. Economic burden of cardiovascular diseases in Serbia. Vojnosanitetski Pregled .2014;71(2):137-43. doi:10.2298/VSP1402137L.

25. Luengo-Fernández R., Leal J., Gray A., Petersen S., Rayner M. Cost of cardiovascular diseases in the United Kingdom. Heart. 2006; 92(10):1384-9. doi: 10.1136/hrt.2005.072173.

\section{Сведения об авторах:}

Концевая Анна Васильевна - Д.м.н., первый зам. директора по научной и аналитической работе, НМИЦ ПМ

Драпкина Оксана Михайловна - Д.М.н., профессор, член-корреспондент РАН, директор НМИЦ ПМ Баланова Юлия Андреевна - К.М.Н., В.Н.С. лаборатории экономического анализа эпидемиологических исследований и профилактических технологий, отдел эпидемиологии хронических неинфекционных заболеваний, НМИЦ ПМ Имаева Асия Эмверовна - К.м.Н., С.н.С., отдел эпидемиологии хронических неинфекционных заболеваний, НМИЦ ПМ Суворова Евгения Игоревна - М.н.С. лаборатории экономического анализа эпидемиологических исследований и профилактических технологий, отдел эпидемиологии хронических неинфекционных заболеваний, НМИЦ ПМ Худяков Михаил Борисович - ведущий инженер лаборатории экономического анализа эпидемиологических исследований и профилактических технологий, отдел эпидемиологии хронических неинфекционных заболеваний, НМИЦ ПМ 